\title{
Phenytoin inhibits necroptosis
}

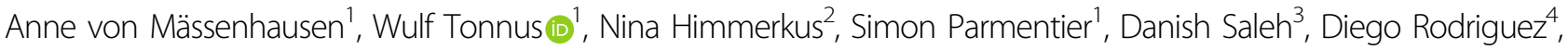 \\ Jiraporn Ousingsawat ${ }^{5}$, Rosalind L. Ang ${ }^{6}$, Joel M. Weinberg ${ }^{7}$, Ana B. Sanz ${ }^{8}$, Alberto Ortiz $\mathbb{0}^{8}$, Adrian Zierleyn ${ }^{1}$, \\ Jan Ulrich Becker ${ }^{9}$, Blandine Baratte ${ }^{10}$, Nathalie Desban ${ }^{10}$, Stéphane Bach $^{10}$, Ina Maria Schiess ${ }^{5}$, Shoko Nogusa ${ }^{11}$, \\ Siddharth Balachandran ${ }^{11}$, Hans Joachim Anders ${ }^{12}$, Adrian T. Ting ${ }^{6}$, Markus Bleich², Alexei Degterev ${ }^{3}$, Karl Kunzelmann" \\ Stefan R. Bornstein ${ }^{1}$, Douglas R. Green ${ }^{4}$, Christian Hugo ${ }^{1}$ and Andreas Linkermann (1)
}

\begin{abstract}
Receptor-interacting protein kinases 1 and 3 (RIPK1/3) have best been described for their role in mediating a regulated form of necrosis, referred to as necroptosis. During this process, RIPK3 phosphorylates mixed lineage kinase domainlike (MLKL) to cause plasma membrane rupture. RIPK3-deficient mice have recently been demonstrated to be protected in a series of disease models, but direct evidence for activation of necroptosis in vivo is still limited. Here, we sought to further examine the activation of necroptosis in kidney ischemia-reperfusion injury (IRI) and from TNFainduced severe inflammatory response syndrome (SIRS), two models of RIPK3-dependent injury. In both models, MLKL-ko mice were significantly protected from injury to a degree that was slightly, but statistically significantly exceeding that of RIPK3-deficient mice. We also demonstrated, for the first time, accumulation of PMLKL in the necrotic tubules of human patients with acute kidney injury. However, our data also uncovered unexpected elevation of blood flow in MLKL-ko animals, which may be relevant to IRI and should be considered in the future. To further understand the mode of regulation of cell death by MLKL, we screened a panel of clinical plasma membrane channel blockers and we found phenytoin to inhibit necroptosis. However, we further found that phenytoin attenuated RIPK1 kinase activity in vitro, likely due to the hydantoin scaffold also present in necrostatin-1, and blocked upstream necrosome formation steps in the cells undergoing necroptosis. We further report that this clinically used anticonvulsant drug displayed protection from kidney IRI and TNFa-induces SIRS in vivo. Overall, our data reveal the relevance of RIPK3-pMLKL regulation for acute kidney injury and identifies an FDA-approved drug that may be useful for immediate clinical evaluation of inhibition of pro-death RIPK1/RIPK3 activities in human diseases.
\end{abstract}

\section{Introduction}

The prevention of necrosis represents a major unmet clinical need ${ }^{1}$. Loss of function of necrotic cells and the immunogenicity of damage-associated molecular patterns drive autoimmunity, ischemic, and toxic organ damages and cancers ${ }^{2}$. The recent understanding of necrosis as a series of regulated cell death pathways (necroptosis ${ }^{3,4}$, ferroptosis $^{5}$, pyroptosis ${ }^{6,7}$ and others) allows targeting of

\footnotetext{
Correspondence: Andreas Linkermann (andreas.linkermann@ukdd.de)

${ }^{1}$ Division of Nephrology, Medical Clinic 3, University Hospital Carl Gustav Carus, Technical University Dresden, Dresden, Germany

${ }^{2}$ Department of Physiology, University of Kiel, Kiel, Germany

Full list of author information is available at the end of the article

These authors contributed equally: Anne von Mässenhausen, Wulf Tonnus.

Edited by $\mathrm{G}$. Melino.
}

necrosis. Necroptosis is the best studied pathway of regulated necrosis and is mediated by RIPK1-mediated activation of RIPK $3^{8-10}$. One of these target proteins, mixed lineage kinase domain like (MLKL), is required for necroptosis ${ }^{11,12}$. However, different RIPK3-targets have recently been demonstrated to contribute to immune modulation in an RIPK3-dependent, but MLKLindependent manner ${ }^{13,14}$. It is therefore unclear if necroptosis or RIPK3-activation independent of cell death modulates the immune system and explains the protective effects of RIPK3-deficient mice in ischemic injury and other diseases, such as the TNF $\alpha$-mediated shock (SIRS) or ischemia-reperfusion injury (IRI). 
Here, we employed MLKL-deficient mice to demonstrate that necroptosis, and not cell death independent functions of RIPK3, contribute to renal IRI and SIRS. In a small-scale screen for plasma membrane channel inhibitors, we found the anticonvulsant phenytoin to prevent necroptosis in vitro and in vivo, potentially offering a therapeutic opportunity for the interference with necroptosis. Finally, we directly detected pMLKL positivity in human biopsy samples obtained from acute kidney injury (AKI) patients and thereby support the pathophysiological evidence for necroptosis in humans.

\section{Results}

MLKL-deficient mice exhibit prolonged survival following TNFa-induced shock

RIPK3-deficient mice have been reported by us and others to be partially protected from SIRS induced by intravenous injection of recombinant $\mathrm{TNF}^{15,16}$, but it remained unclear which downstream RIPK3 target mediates this protection. Fig. 1a demonstrates that MLKLdeficient mice phenocopy the partial protection of RIPK3ko mice. Interestingly, MLKL-deficient mice exhibited a significantly different level of protection not only when compared with wild-type mice, but also in comparison with the RIPK3-ko animals. However, as most of these mice die, the protective effect of the MLKL-ko mice is much less protected than RIPK1-kinase dead knock-in mice $^{17-19}$, or caspase-8/RIPK3-dko mice ${ }^{20}$.

\section{MLKL-deficient mice phenocopy the protection from ischemia-reperfusion injury observed in RIPK3-deficient mice}

Human AKI is characterized by various morphologically different forms of tubular necrosis (Figure S1), and targeting necrosis may be of particular benefit for patients suffering from AKI. To study the best characterized mode of regulated necrosis, necroptosis, we knocked down RIPK3 or MLKL from murine kidney cells (MCTs) and found protection from necroptosis induced by TNF $\alpha /$ TWEAK/Interferon- $\gamma$ in the presence of the pan-caspase inhibitor zVAD-fmk (Fig. 1b, c). In addition, in a wellestablished model of murine IRI, MLKL-deficient mice exhibited less structural damage (Fig. 1d, e) and less severe functional AKI (Fig. 1f, g) when compared with wild-type mice. Given the previously observed protection of RIPK3-ko in renal IRI ${ }^{21}$, we included RIPK3-deficient mice into this study. Similar to the results in the SIRS model (Fig. 1a), we documented a trend towards superior protection in MLKL-ko mice in histology, renal damage scores, and functional markers of AKI such as serum creatinine (Fig. 1d, e, g). However, this trend reached statistical significance in the case of serum urea concentrations (Fig. 1f). These data indicate that MLKL mediates necroptosis in SIRS and renal IRI and suggest that RIPK3-dependent, MLKL-independent effects are of minor importance in these models.

\section{Detection of phospho-MLKL in human biopsies obtained from patients with acute kidney injury}

Until today, and despite the broad general interest, activity of the necroptosis pathway has been detected in humans only in kidney transplant biopsies, but expression of pMLKL in those studies was not associated with a morphological phenotype of necrosis ${ }^{22}$. Given the very clear contribution of necrosis to human AKI (Figure S1A$D)^{23}$, we investigated biopsies obtained from patients that suffered from AKI for pMLKL-positivity using a previously described method ${ }^{22}$. Employing a specific monoclonal antibody of a human pMLKL, we found pMLKL positivity in about $5 \%$ of AKI samples in $10-15 \%$ of the affected tubules (Fig. 2a). To our knowledge, these samples exhibit the first detection of necroptosis in human conditions as they are clearly associated with a necrotic morphology. However, several samples showed necrotic tubules the majority of which did not stain positive for pMLKL, suggesting the parallel existence of other pathways of regulated necrosis. To understand the function of pMLKL in disease models, we employed a previously established ex vivo approach in which we use hand-picked primary kidney tubules. Whereas MLKL-deficient tubules are not protected from hypoxia-reoxygenation per se (Figure S2A-C), they appear to undergo delayed synchronized tubular necrosis (STN) upon erastinstimulation (Fig. 2c), a compound that induces another type of regulated necrosis referred to as ferroptosis ${ }^{24,25}$. Taken together, these experiments suggest a role for pMLKL in SIRS, renal IRI in mice and humans and erastin-induced STN in mice, but not in isolated settings of hypoxia-driven damage ex vivo. Given (i) this virtual discrepancy and (ii) our previous observations of either the necroptosis-inhibitor Nec-1 or RIPK3-deficiency to directly influence on capillary blood flow ${ }^{21,26}$, we hypothesized that changes in the vasculature of MLKLdeficient mice might contribute to the observed protective effects in the disease models.

\section{MLKL-deficient mice spontaneously exhibit accelerated peritubular blood flow}

Capillary endothelial cells are of interest in both renal IRI and SIRS. We investigated MLKL-deficient mice in intravital microscopy in a strictly double-blinded fashion (Fig. 2d). Strikingly, MLKL-ko mice exhibit much higher blood velocity and stronger overall flow in the peritubular capillaries (Fig. 2e, f). Importantly in this setting, the mean arterial blood pressure was indistinguishable from either group of littermates (Fig. 2g). This phenomenon might contribute to the protection from IRI, and may also be of importance in the SIRS model. Taken together, our 


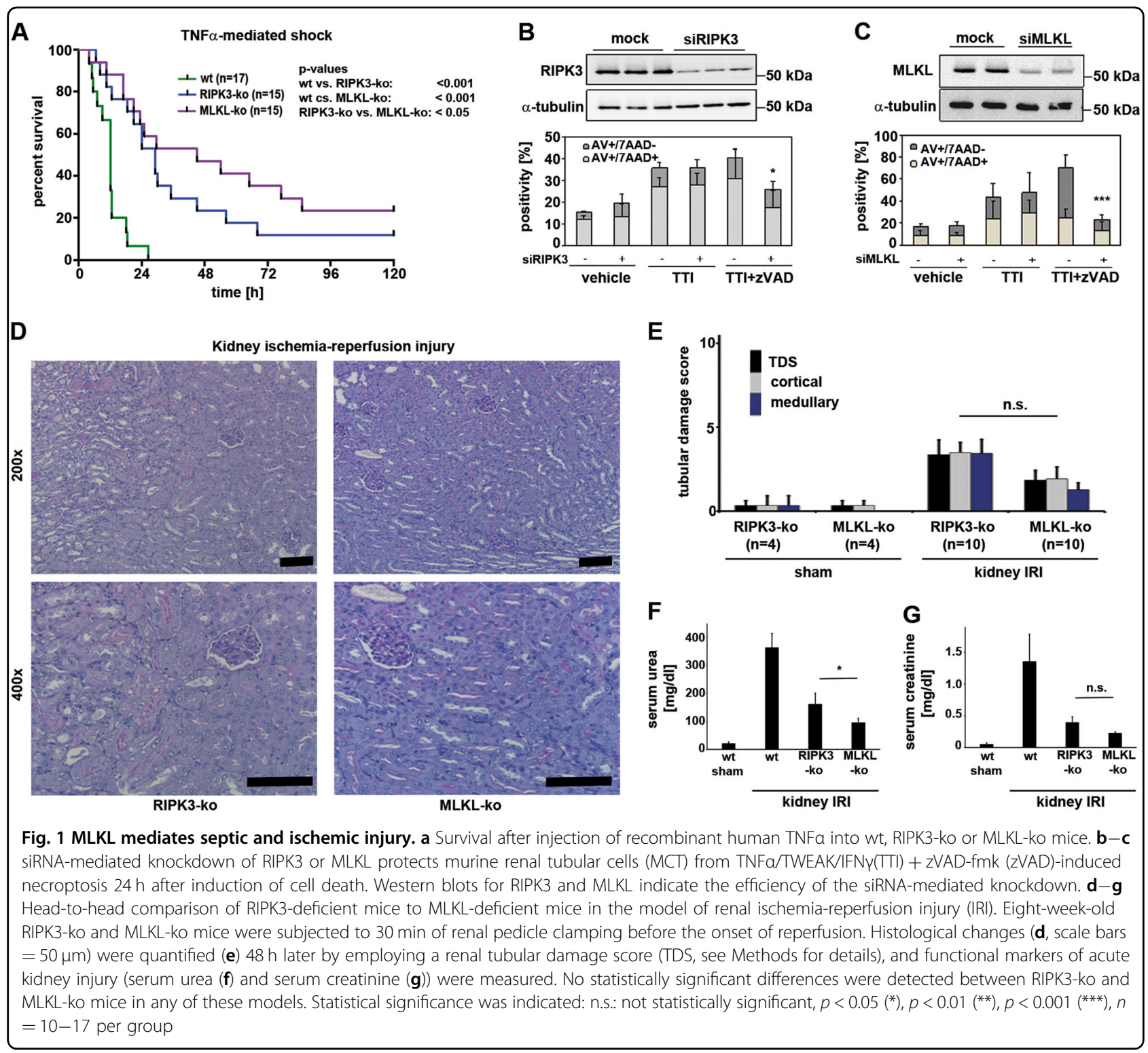

results suggest a combined role of MLKL in (i) directly mediating the damage to the parenchymal cells and (ii) regulating blood flow. The mechanism of the latter remains to be investigated in more detail.

\section{A cellular hypothesis-driven screen identifies phenytoin to prevent necroptosis}

Based on the above-mentioned findings and the recent observation that necroptosis regulation downstream of pMLKL by the ESCRT-III complex critically modulates the kinetics of necroptotic cell death ${ }^{22}$, we challenged the current model in which a pMLKL inevitably results in necroptosis. To test this, we treated HT29 cells with TSZ to induce necroptosis and added the MLKL-inhibitor necrosulfonamide $(\mathrm{NSA})^{11}$. We investigated three time points up to $24 \mathrm{~h}$ and split the cell culture to be read out by fluorescence-activated cell sorting (FACS) and western blot. As demonstrated in Fig. 3a, b, within $4 \mathrm{~h}$ of TSZtreatment, NSA-incubated cells clearly became positive for pMLKL, but all of these cells were negative for both annexin $\mathrm{V}$ and 7AAD. In the progression of this experiment until $24 \mathrm{~h}$, pMLKL-positive cells did not undergo cell death during this time despite a strong pMLKL signal, clearly demonstrating that positivity for pMLKL is not sufficient to drive necroptosis.

If pMLKL is required but not sufficient for necroptosis execution and the swelling of the cells, we tested the hypothesis that plasma membrane channels may be involved downstream of pMLKL by a small-scale, hypothesis-driven screen with FDA-approved drugs that 
A

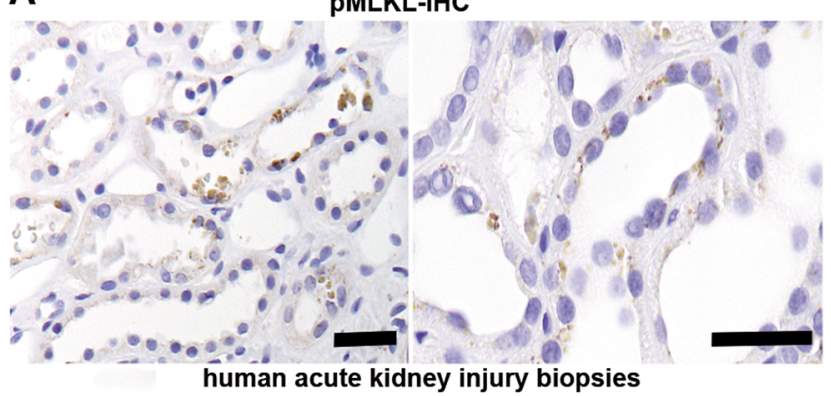

C

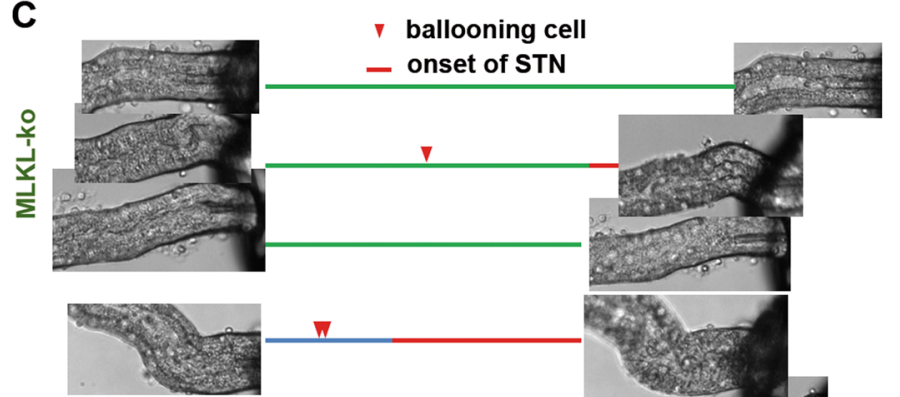

$\frac{\sum^{2}}{\frac{0}{3}}$

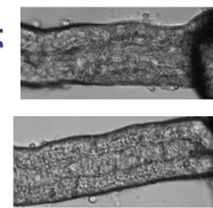

B

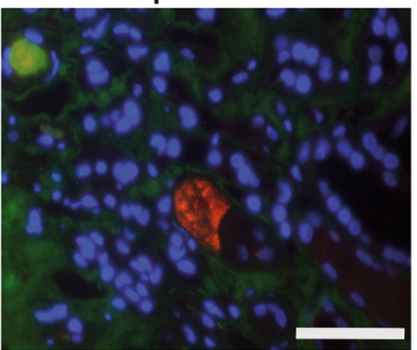

human cristallopathy
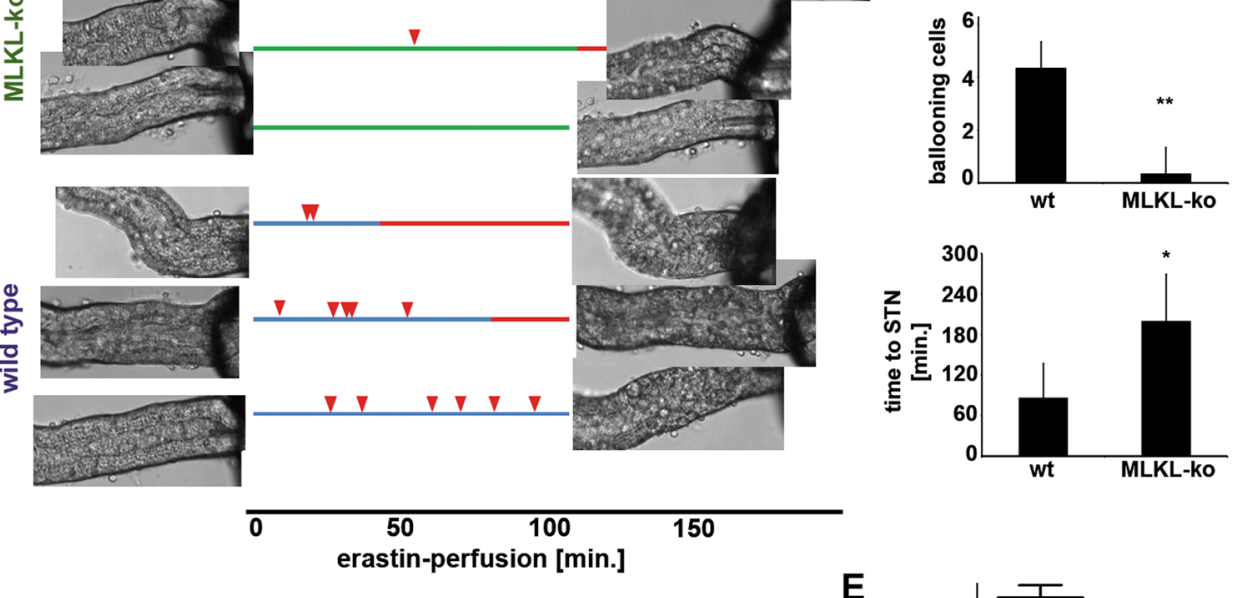

D

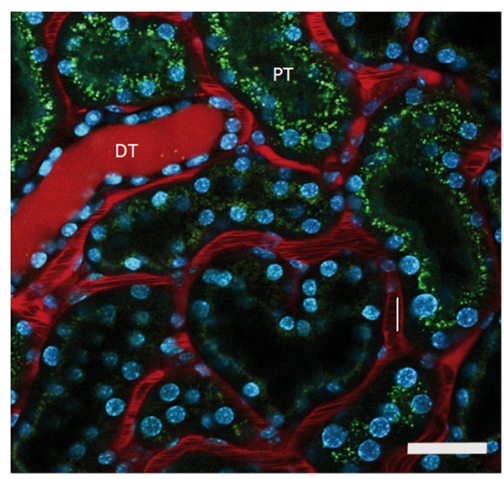

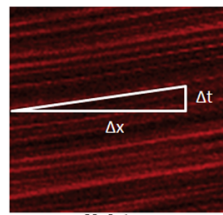

wild type

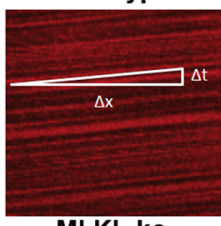

E

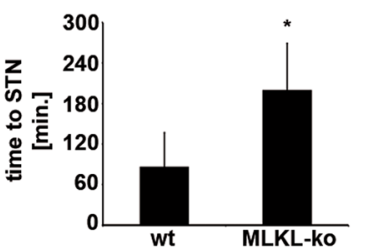

Fig. 2 Detection of the human relevance of necroptosis and the role of MLKL. a Human kidney transplant biopsies obtained from patients 4 days following ischemia-reperfusion injury were stained for pMLKL. b Immunofluorescence of a renal biopsy sample taken from a patient with diagnosed crystallopathy. c Freshly isolated hand-picked kidney tubules from either wt or MLKL-ko mice were perfused with the ferroptosis-inducing compound erastin and video-monitored for morphological changes (compare Video S1). Ballooning cells are indicated as spikes on the time charts corresponding to each experiment. Change of color of the time chart indicates the onset of synchronized tubular necrosis (STN) of all cells of the tubules. Note that MLKL-ko mice exhibit highly significantly less ballooning cells and longer time to the onset of STN. $\mathbf{d}$ High-resolution intravital microscopy of MLKL-ko and wild-type littermates was employed to measure e velocity and $\mathbf{f}$ flow in the peritubular capillaries. In addition, mean arterial pressure (MAP) was quantified. Note the strong reduction in peritubular flow. Statistical significance was indicated: n.s.: not statistically significant, $p<0.05\left(^{*}\right), p<0.01\left(^{* *}\right), p<0.001\left(^{* * *}\right)$. Scale bars $=50 \mu \mathrm{m}$ 


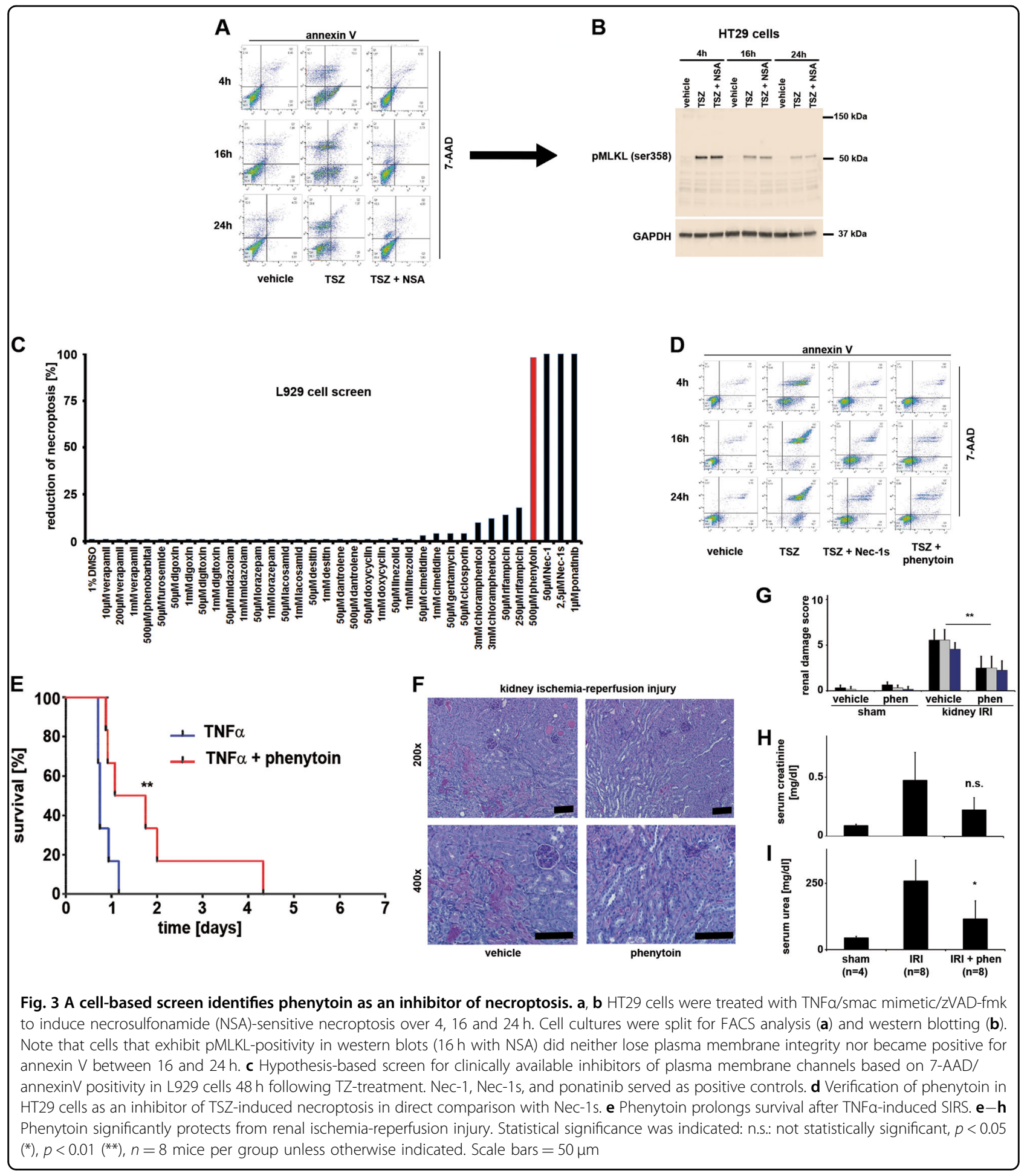

are known to exert inhibitory effects on plasma membrane channels (Fig. 3c). We found the anticonvulsive drug phenytoin (Dilantin) to protect from necroptosis as efficiently as Nec-1 $24 \mathrm{~h}$ after necroptosis induction (Fig. 3c, d) and confirmed this result in various necroptosis-sensitive cell lines (Figure S3). We next investigated phenytoin in the in vivo models. In the SIRS model, phenytoin slightly, but significantly delayed the time to death after TNF-injection (Fig. 3f), and in the renal IRI model, application of phenytoin attenuated histological damage (Fig. 3g, h) and functional markers of AKI (Fig. 3i, j). 


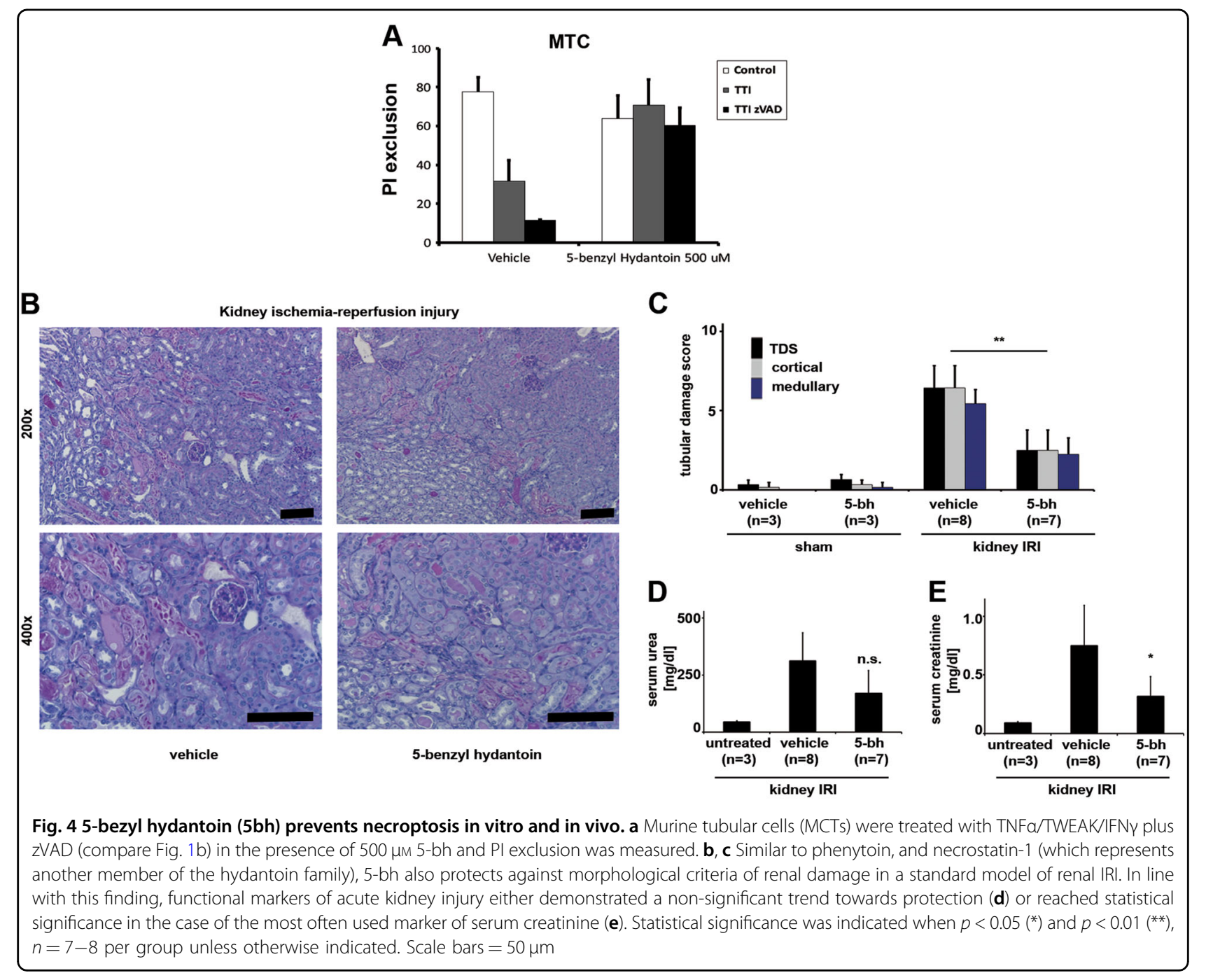

As both Nec-1 and phenytoin are hydantoins, we hypothesized that other hydantoins may function similarly. We therefore investigated 5-benzyl hydantoin in the renal tubular cells treated with TTI-zVAD-fmk (compare Fig. 1b, c). Indeed, we found that also 5-benzyl hydantoin effectively prevented necroptosis in vitro (Fig. 4a) and in vivo in renal injury following kidney IRI (Fig. 4b, e).

\section{Phenytoin prevents necrosome formation and partially inhibits RIP1 kinase}

Similar to Nec-1s, phenytoin prevented phosphorylation of MLKL during necroptosis, ruling out an antinecroptotic effect on downstream mechanisms (Fig. 5a). To identify the mechanism of action of phenytoin, we investigated the effects of phenytoin on kinase activity of RIPK1 and RIPK3, by performing a kinase inhibition screen with high doses $(50 \mu \mathrm{M}$ to $500 \mu \mathrm{M})$ of phenytoin. The only kinase that was affected by this incubation was
RIPK1 (Fig. 5b). However, in cell-free systems employing RIPK1 autophosphorylation assays (see Methods section for details), the inhibitory effect was much less pronounced when compared with the highly specific RIP1 kinase inhibitor Nec-1s (Fig. 5c). We next looked at the RIPK1 enrichment in the necrosome NP40 insoluble fractions and found that it was strongly affected by phenytoin (Fig. 5d) in HT29 cells and RAW.264 cells (Fig. 5e), as was the recruitment of RIPK3 and its oligomerization to the necrosome (Fig. 5e). We confirmed the absence of the pMLKL signal in wild-type MEFs (Fig. 5f) and employed these cells for RIPK3 immunoprecipitation to find that the formation of the necrosome was clearly reduced (Fig. 5g). In an immunoprecipitation with an anti-FADD antibody, phenytoin prevented RIPK1 recruitment to FADD in L929 cells (Fig. 5h). When we used forced RIPK3 dimerization employing the AP-1 dimerizer system, we confirmed that phenytoin prevents 


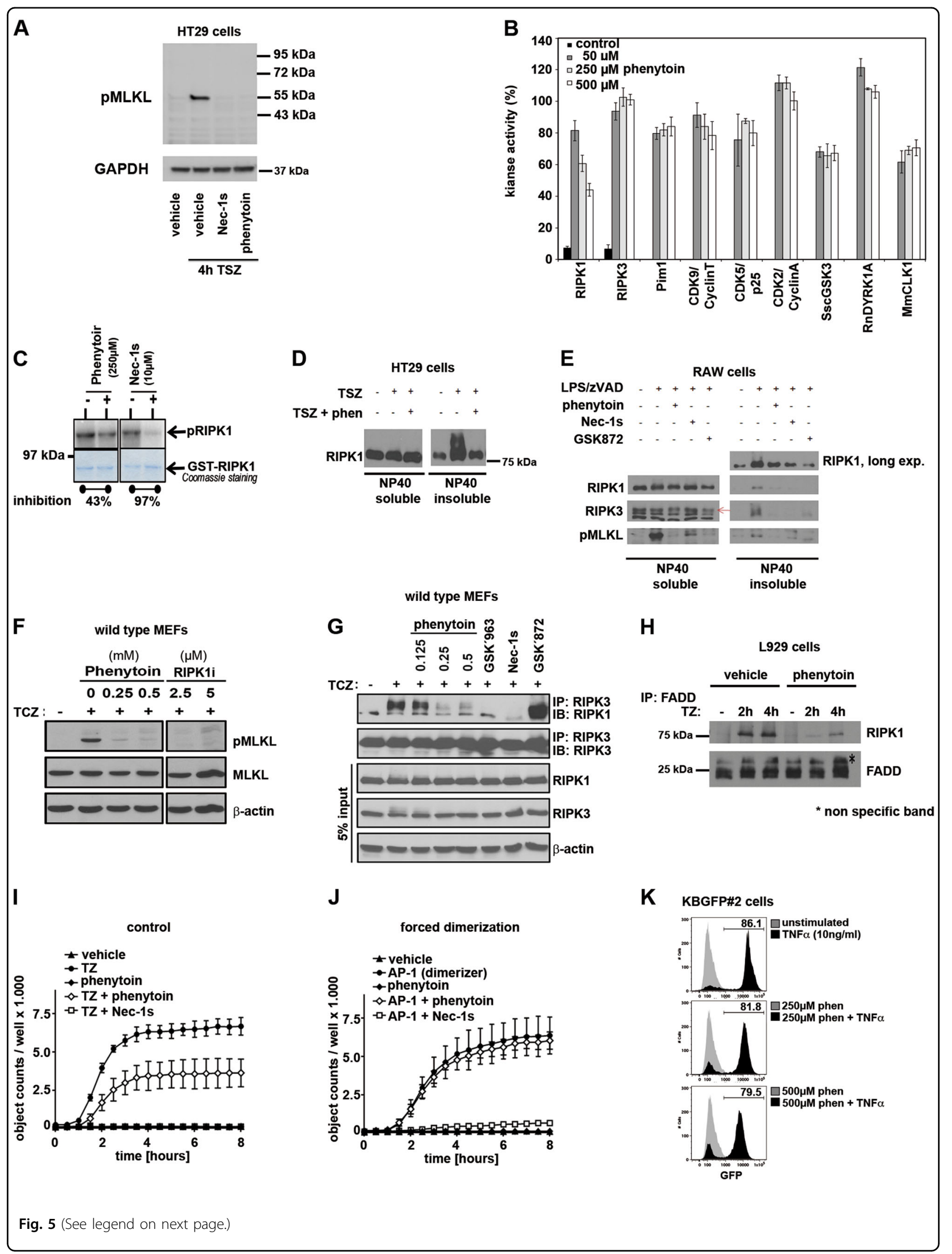




\begin{abstract}
(see figure on previous page)
Fig. 5 Phenytoin prevents the formation of the necrosome. a HT29 cells were treated with TSZ for $4 \mathrm{~h}$ and stained for human pMLKL. Note that phenytoin prevents the phosphorylation of MLKL as effectively as Nec-1s. b Screen for kinase inhibition by phenytoin reveals no major inhibition of any of the kinases investigated, including RIPK1 and RIPK3. c RIPK1 autophosphorylation assay as described in detail in the Methods section. $250 \mu \mathrm{M}$ phenytoin result in 43\% inhibition of RIPK1 autophosphorylation; Nec-1s serves as positive control. $\mathbf{d}$ HT-29 cells were treated with TSZ and phenytoin as indicated and NP40 soluble and insoluble fractions were separated before RIPK1 western blotting. e RAW cells were treated with LPS/zVAD-fmk (L/ Z), phenytoin, Nec-1s and the RIPK3-inhibitor GSK872 as indicated. NP40 soluble and insoluble fractions were separated and stained for RIPK1 (short and long exposure), RIPK3 and pMLKL. f, g Primary wild-type MEFs were treated with TNF-a $(50 \mathrm{ng} / \mathrm{ml})$ in the presence of CHX (200 ng/ml) and zVAD $(50 \mu \mathrm{m})$, with or without pre-treatment with indicated doses of phenytoin or RIPK1 inhibitor GSK'963 (indicated doses in (f), $5 \mu \mathrm{m}$ in $\mathbf{g})$ or Nec-1 (50 $\mu \mathrm{m}$ ) or RIPK3 inhibitor GSK'872 (5 $\mu \mathrm{m})$. pMLKL western blotting and RIPK3 immunoprecipitations were performed on lysates after $6 \mathrm{~h}$ and examined for necrosome formation by immunoblotting for RIPK1. $\mathbf{h}$ L929 cells were seeded on $100 \mathrm{~mm}$ plate and then stimulated with hTNF $(10 \mathrm{ng} / \mathrm{ml})$ in the presence/absence of zVAD-fmk (10 $\mu \mathrm{m})$ and phenytoin $(500 \mu \mathrm{m})$ for 2 and $4 \mathrm{~h}$. Cells were then lysed in NP-40 lysis buffer $(0.2 \%$ NP-40, 20 mM Tris, 150 $\mathrm{mm} \mathrm{NaCl}$ and $10 \%$ glycerol, at pH 7.5) for $30 \mathrm{~min}$ in ice. Samples were centrifuged at 20,000 $\times \mathrm{g}$ for $15 \mathrm{~min}$ and supernatants were incubated with FADD-specific antibody (M-19, Santa Cruz Biotechnology) overnight at $4{ }^{\circ} \mathrm{C}$. Protein A/G beads (Santa Cruz Biotechnology) were added for a further 3 $h$. The beads were then washed five times with cold lysis buffer and FADD-associated proteins were eluted following incubating the beads in SDSPAGE loading buffer at $70^{\circ} \mathrm{C}$ for $20 \mathrm{~min}$. $\mathbf{i}, \mathbf{j}$ NIH3T3 + RIPK3-2xFV were incubated in absence or presence of 0.125 mm phenytoin in combination with $10 \mathrm{ng} / \mathrm{ml}$ of TNF plus 25 um zVAD (g) or $2 \mathrm{~nm}$ AP-1 (homodimerizer; AP-20187) (h). Cell death was monitored by Sytox Green uptake by using an incucyte Kinetic Live Cell Imager. Alternatively, cell death was prevented by using $30 \mu \mathrm{m}$ of Nec-1s (RIPK1 inhibitor) or 1 Mm GSK'872 (RIPK3 inhibitor), respectively. $\mathbf{k}$ KBGFP\#2 cells were seeded on six-well plate and then stimulated with hTNF $(10 \mathrm{ng} / \mathrm{ml}$ ) in the presence/absence of phenytoin (either $250 \mu \mathrm{m}$ or $500 \mu \mathrm{m})$ for $24 \mathrm{~h}$. Cells were then trypsinized and washed once with cold PBS. The GFP expression was analyzed by flow cytometry
\end{abstract}

necrosis also in these artificially engineered cells (Fig. 5i), but forced dimerization of RIPK3 was sufficient to overcome the phenytoin-mediated protection from necroptosis (Fig. 5j). Additionally, phenytoin did not affect $\mathrm{TNF} \alpha$-mediated signaling towards the NF- $\mathrm{KB}$ complex (Fig. 5k).

We next sought to investigate the electrophysiology in the pathway of necroptosis. As expected, we detected a whole cell current during necroptosis (Fig. 6a) that was sensitive to NSA, but also to chloride (Fig. 6b). In addition, the intracellular changes in calcium concentrations during necroptosis were no higher than $300 \mathrm{~nm}$ (Fig. 6c) as compared to $10 \mu \mathrm{M}$ in apoptosis. However, the Ca-signal during necroptosis was sensitive to NSA and to dantrolene (Fig. 6d), but similar concentrations of dantrolene did not affect necroptotic cell death (Fig. 3d). In contrast, phenytoin did not affect the calcium signal (Fig. 6e), but did block necroptosis (Fig. 6e). However, the dantrolenesensitive calcium signal does not affect necroptosis and was not studied further.

In summary, these results suggest that phenytoin prevents necroptosis by an undefined mechanism that might partially involve RIP1 kinase inhibition whereas NF-kB signaling is not affected. One possibility is that RIPK1 is kept in an inactive conformation by high doses of phenytoin that may prevent the interaction with other players in the necroptosis pathway.

\section{Discussion}

With our increasing understanding of RIPK3 biology, it becomes important to distinguish between necroptotic and non-necroptotic functions of RIPK3. Therefore, unlike RIPK3-deficiency, MLKL-deficient mice provide an ideal target to study necroptosis. We demonstrated that MLKL-dependent necroptosis contributes to the pathophysiology in mouse models of kidney IRI and SIRS, largely ruling out pathophysiologically important nonnecroptotic roles of RIPK3 in these models. Given the quality of the anti-human pMLKL antibody, it is possible to detect necroptosis directly in human samples. However, even cell death independent functions of MLKL appear to contribute as MLKL-deficient mice exhibit increased peritubular blood flow.

It was previously reported that RIPK3 deficiency provides greater benefit than MLKL deficiency in mouse models of inflammation and tissue injury ${ }^{16}$. Our data do not support this general conclusion, at least not for kidney IRI and the TNF $\alpha$-mediated SIRS, but confounding factors such as microbiota may explain these differences. However, our data presented here are in line with the conclusion that necroptosis is an important therapeutic target.

Most of the currently investigated RIPK1 inhibitors function in low micromolar range. We report that phenytoin, despite being an RIPK1 inhibitor, is at least two orders of magnitude less potent in preventing necroptosis. However, phenytoin is a hydantoin and it turns out that it displays an activity against RIPK1 kinase. This may be generally true for hydantoins as benzyl-hydantoin also displays inhibition of necroptosis. Alternatively, however, a growing body of evidence suggests that RIPK1 function are not always associated with its kinase activity, but may also be explained by kinase-independent scaffolding modes. Clearly, the necrosome assays suggest that phenytoin acts at an early step of necrosome formation, but certainly much less potent than highly specific 


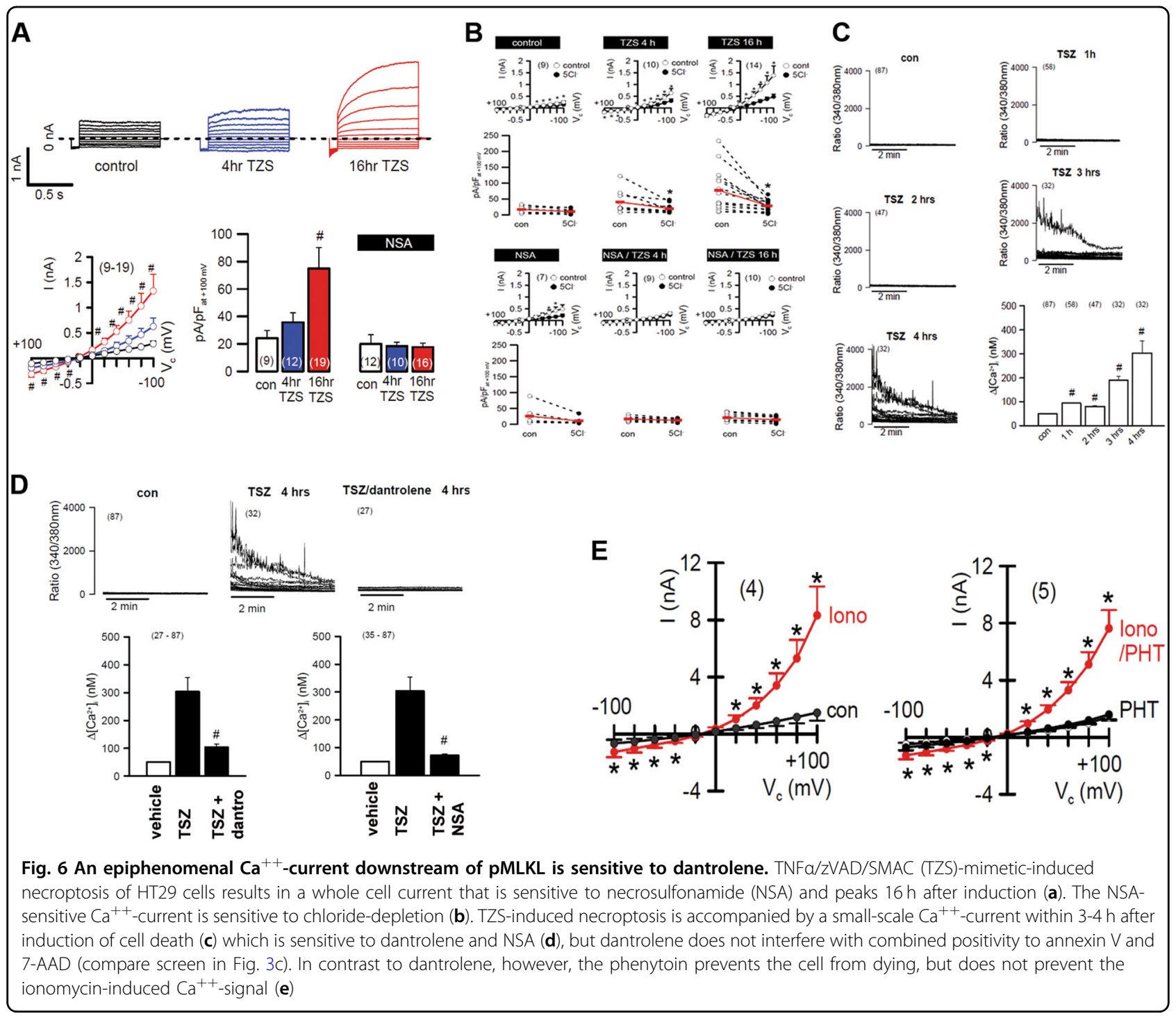

necrostatins. Therefore, even if it was considered to perform clinical studies-because of the low costs, clinical experience, and general availability of phenytoin-data on the in vivo concentrations of phenytoin in the targeted organs are urgently awaited. Several clinical trials employing inhibitors of RIPK1 have been initiated as novel anti-necroptosis therapies emerged ${ }^{3,27-30}$. Despite the potential of these small molecules, none of these compounds reached phase III clinical studies today. With greater than 60 years of clinical experience and low costs alongside with the availability on ICUs and in ambulances, phenytoin may provide a drug to target necroptosis.

Finally, it remains to be investigated whether typical side effects of phenytoin that generally occur years after the onset of chronical treatment, such as gingival hyperpla$\mathrm{sia}^{31}$, may be explained by a failure to induce necroptosis or necroinflammation ${ }^{32}$.

\section{Materials and methods}

\section{Reagents, cell lines, and cell death assays}

Necrostatin (Nec-1) was obtained from Sigma-Aldrich. The zVAD-fmk (herein referred to as zVAD) was purchased from BD Biosciences. SMAC-mimetics (Birinapant) was from Absource Diagnostics (Selleckchem). Murine NIH3T3 fibroblasts were originally obtained from ATCC and were cultured in Dulbecco's modified Eagle medium (DMEM) (Invitrogen) supplemented with 10\% (vol/vol) FCS, $100 \mathrm{U} / \mathrm{ml}$ penicillin, and $100 \mu \mathrm{g} / \mathrm{ml}$ streptomycin. Murine kidney cortical tubular cells (MCTs) were originally generated from the cortex of SJL mice by Eric Neilson at the University of Pennsylvania. All cell lines were cultured in a humidified $5 \% \mathrm{CO}_{2}$ atmosphere. For induction of necroptosis, HT29 cells were stimulated for $24 \mathrm{~h}$ at $37^{\circ} \mathrm{C}$ with $100 \mathrm{ng} / \mathrm{ml}$ TNFo plus $1 \mu \mathrm{M}$ SMACmimetics plus $25 \mu \mathrm{m}$ zVAD-fmk as indicated (vehicle- 
treated cells served as control). For immunoblotting, cells were lysed in ice-cold $10 \mathrm{~mm}$ Tris. $\mathrm{HCl}, \mathrm{pH} 7.5,50 \mathrm{~mm}$ $\mathrm{NaCl}, 1 \%$ Triton $\mathrm{X}-100,30 \mathrm{~mm}$ sodium pyrophosphate, $50 \mathrm{~mm} \mathrm{NaF}, 100 \mu \mathrm{M} \mathrm{Na}_{3} \mathrm{VO}_{4}, 2 \mu \mathrm{M} \mathrm{ZnCl}_{2}$, and $1 \mathrm{~mm}$ phenylmethylsulfonyl fluoride (modified Frackelton buffer). Insoluble material was removed by centrifugation $\left(14,000 \times g, 10 \mathrm{~min}, 4{ }^{\circ} \mathrm{C}\right)$, and protein concentration was determined using a commercial Bradford assay kit according to the manufacturer's instructions (Bio-Rad). Equal amounts of protein (17 $\mu \mathrm{g}$ per lane) were resolved on a $12 \%$ SDS/PAGE gel and transferred to a nitrocellulose membrane (Amersham Biosciences). Immune complexes were visualized by enhanced chemiluminescence (ECL; Amersham Biosciences). NIH3T3 + RIPK3-2xFV and the AP-1 dimerizer system have been described previously ${ }^{19}$. Cell viability was additionally assessed in RAW264.7 macrophages, seeded at 20,000 per well in 96well format. Cells were treated for $24 \mathrm{~h}$. Cell viability was assessed by total ATP release using Promega CellTiterGlo reagent. Necroptosis in MCT cells was induced by a combination of $30 \mathrm{ng} / \mathrm{ml}$ TNF, $100 \mathrm{ng} / \mathrm{ml}$ TWEAK, and $300 \mathrm{IU} / \mathrm{ml}$ Interferon- $\gamma$ in the presence of $25 \mu \mathrm{m} \mathrm{zVAD-}$ fmk for $24 \mathrm{~h}$. Primary wild-type MEFs were generated inhouse from E14.5 embryos and used within ten passages in experiments. Biological and chemical reagents were from the following sources: cycloheximide (MP Biomedicals), Necrostatin 1 (BioVision), zVAD-fmk (Bachem), Phenytoin, and TNF- $\alpha$ (R\&D Systems). Inhibitors of RIPK1 $\left(\right.$ GSK'$^{\prime} 93^{33}$ ) and RIPK3 (GSK'872 ${ }^{34}$ ) from GlaxoSmithKline have been described before. Antibodies for immunoblot analysis of $\beta$-actin (Sigma), MLKL (Abgent), murine pMLKL (Abcam, ab196436), human pMLKL (Abcam, ab187091), RIPK1 (BD Transduction labs), RIPK3 (ProSci or Santa Cruz) were obtained from the indicated commercial sources.

\section{Fluorescence-activated cell sorting}

Phosphatidylserine exposure to the outer cell membrane of apoptotic cells or at the inner plasma membrane of necrotic cells and incorporation of 7-AAD into necrotic cells were quantified by the FACS analysis. The ApoAlert annexin V-FITC antibody and the 7-AAD antibody were purchased from BD Biosciences.

\section{Necrosome isolation assay}

Necrosome isolation assay was adapted from previously described methods ${ }^{20,21}$. RAW264.7 macrophages were treated for $4 \mathrm{~h}$ and harvested using a 1\% NP40-containing lysis buffer (150 mM NaCl, $20 \mathrm{~mm}$ Tris-Cl (pH 7.5), 1\% NP-40, $1 \mathrm{~mm}$ EDTA, $3 \mathrm{~mm} \mathrm{NaF}, 1 \mathrm{~mm}$ B-glycerophosphate, $1 \mathrm{~mm}$ sodium orthovanadate, $5 \mu \mathrm{m}$ Iodoacetamide, $2 \mu \mathrm{M} \quad N$-ethylmaleimide) supplemented with $1 \mu \mathrm{g} / \mathrm{ml}$ Aproprotinin, Leupeptin, and Pepstatin, and $0.5 \mu \mathrm{g} / \mathrm{ml}$ PMSF. Lysates were flash frozen on dry-ice, thawed, and then centrifuged at $1000 \times g$ for $10 \mathrm{~min}$ to precipitate nuclear matter. Supernatant was recovered and centrifuged at $34,400 \times g$ to pellet NP40-insoluble matter (necrosome fraction). Resulting supernatant was collected as NP-40-soluble fraction. Necrosome fraction was boiled in 1× Laemmli buffer for 5-10 min and triturated until pellet was dispersed. NP-40-soluble and necrosome fractions were probed for RIPK1 (Cell Signaling, 3493), RIPK3 (Pro-Sci, 2283), and phospho-S345 mMLKL (Abcam, ab196436) by western analysis.

\section{Detection of the RIPK3 necrosome}

$7.5 \times 10^{5}$ cells per condition were lysed in TL buffer $(1 \%$ Triton X-100, $150 \mathrm{~mm} \mathrm{NaCl}, 20$ mм HEPES, 5 mм EDTA, $5 \mathrm{~mm} \mathrm{NaF}, 0.2 \mathrm{~mm}$ sodium ortho-vanadate) supplemented with Complete Mini ${ }^{\circ}$ protease inhibitor cocktail (Roche) and briefly sonicated. Lysates were clarified by centrifugation at $14,000 \mathrm{rpm}$ for $10 \mathrm{~min}$ at $4{ }^{\circ} \mathrm{C}$, and antiRIPK3 antibody ( $2 \mu \mathrm{g}$ of ProSci or $10 \mu \mathrm{g}$ of Santa Cruz) was added to each sample. After overnight incubation at $4{ }^{\circ} \mathrm{C}$ with rotation, samples were supplemented with $30 \mu \mathrm{l}$ of twice-washed protein A/G-agarose slurry (Thermo Scientific) and incubated for additional $2 \mathrm{~h}$, washed three times with cold TL buffer, eluted by boiling in SDS sample buffer, and resolved by SDS-PAGE. RIPK3 necrosome components were then detected by immunoblotting.

\section{Isolation of primary murine tubules}

Six to 12 mice were used for each isolated tubule preparation, depending on the amount of material needed for particular experiments. For preparation of isolated tubules, mice were anesthetized with ketamine $(100 \mathrm{mg} /$ $\mathrm{kg}$ i.p.) and xylazine (10 $\mathrm{mg} / \mathrm{kg}$ i.p.), and the kidneys were immediately removed. Type I collagenase was from Worthington Biochemical. Percoll was purchased from Amersham Biosciences. All other reagents and chemicals, including delipidated BSA, were of the highest grade available from Sigma-Aldrich. Immediately after removal of the kidneys, the parenchyma was injected with 0.3-0.5 cc of a cold $95 \% \mathrm{O}_{2} / 5 \% \mathrm{CO}_{2}$-gassed solution consisting of $115 \mathrm{~mm} \mathrm{NaCl}, 2.1 \mathrm{~mm}$ KCI, $25 \mathrm{~mm} \mathrm{NaHCO}, 1.2 \mathrm{~mm}$ $\mathrm{KH}_{2} \mathrm{PO}_{4}, 2.5 \mathrm{~mm} \mathrm{CaCl} 2,1.2 \mathrm{~mm} \mathrm{MgCl}, 1.2 \mathrm{~mm} \mathrm{MgSO}_{4}$, $25 \mathrm{~mm}$ mannitol, $2.5 \mathrm{mg} / \mathrm{ml}$ fatty acid-free BSA, $5 \mathrm{~mm}$ glucose, $4 \mathrm{~mm}$ sodium lactate, $1 \mathrm{~mm}$ alanine, and $1 \mathrm{~mm}$ sodium butyrate (solution A) with the addition of $1 \mathrm{mg} / \mathrm{ml}$ collagenase (type I; Northington Biochemical). The cortices were then dissected and minced on an ice-cold tile and then suspended in additional solution A for 8-10 min of digestion at $37^{\circ} \mathrm{C}$, followed by enrichment of proximal tubules using centrifugation on self-forming Percoll gradients. The fragments were transferred to collagenase solution (DS with $0.1 \%$ (wt/vol) type 2 collagenase and 96 $\mu \mathrm{g} / \mathrm{ml}$ soybean trypsin inhibitor) and digested for $30 \mathrm{~min}$ at $37^{\circ} \mathrm{C}$ and $850 \mathrm{rpm}$. After digestion, the supernatant was 
sieved through two nylon sieves: first $250-\mu \mathrm{m}$ pore size and then $100-\mu \mathrm{m}$ pore size. The longer proximal tubule segments remaining in the $100-\mu \mathrm{m}$ sieve were suspended by flushing the sieve in the reverse direction with warm DS $\left(37^{\circ} \mathrm{C}\right)$ containing BSA $1 \%(\mathrm{wt} / \mathrm{vol})$. The proximal tubule suspension was centrifuged for $5 \mathrm{~min}$ at $170 \times g$, washed, and then suspended into the appropriated amount of culture medium (1:1 DMEM/F12 without phenol red and supplemented with heat-inactivated $1 \%$ FCS, $15 \mathrm{mmol} / \mathrm{l} \mathrm{Hepes,} 2 \mathrm{mmol} / \mathrm{l} \mathrm{L}$-glutamine, $50 \mathrm{nmol} / \mathrm{l}$ hydrocortisone, $5 \mu \mathrm{g} / \mathrm{ml}$ insulin, $5 \mu \mathrm{g} / \mathrm{ml}$ transferrin, $5 \mathrm{ng} /$ $\mathrm{ml}$ sodium selenite, $0.55 \mathrm{mmol} / \mathrm{l}$ sodium pyruvate, $10 \mathrm{ml} / \mathrm{l}$ $100 \times$ nonessential amino acids, $100 \mathrm{IU} / \mathrm{ml}$ penicillin, and $100 \mu \mathrm{g} / \mathrm{ml}$ streptomycin buffered to $\mathrm{pH} 7.4$ (osmolality of $325 \mathrm{mOsmol} / \mathrm{kg} \mathrm{H}_{2} \mathrm{O}$ )). The proximal tubule fragments were seeded onto a tissue culture plate and cultured at 37 ${ }^{\circ} \mathrm{C}$ and $95 \%$ air $/ 5 \% \mathrm{CO}_{2}$ in a standard humidified incubator.

\section{Experimental procedures for, and movies of, freshly isolated tubules}

Tubules were suspended at 2.0-3.0 mg of tubule protein per milliliter in a $95 \%$ air $/ 5 \% \mathrm{CO}_{2}$-gassed medium containing $110 \mathrm{~mm} \mathrm{NaCl}, 2.6 \mathrm{~mm} \mathrm{KCl,} 25 \mathrm{~mm} \mathrm{NaHCO}, 2.4$ $\mathrm{mm} \quad \mathrm{KH}_{2} \mathrm{PO}_{4}, \quad 1.25 \mathrm{~mm} \quad \mathrm{CaCl}_{2}, 1.2 \mathrm{mMMgCl}_{2}, 1.2$ $\mathrm{mMMgSO}_{4}, 5 \mathrm{~mm}$ glucose, $4 \mathrm{~mm}$ sodium lactate, $0.3 \mathrm{~mm}$ alanine, $5 \mathrm{~mm}$ sodium butyrate, $2 \mathrm{~mm}$ glycine, and $1.0 \mathrm{mg} /$ $\mathrm{ml}$ bovine gelatin (75 bloom) (solution B). For studies comparing normoxia with hypoxia/reoxygenation, at the end of $15 \mathrm{~min}$, preincubation tubules were resuspended in fresh solution $\mathrm{B}$ and regassed with either $95 \%$ air $/ 5 \% \mathrm{CO}_{2}$ (normoxic controls) or $95 \% \mathrm{~N}_{2} / 5 \% \mathrm{CO}_{2}$ (hypoxia). During hypoxia, solution $\mathrm{B}$ was kept at $\mathrm{pH} 6.9$ to simulate tissue acidosis during ischemia in vivo, and the usual substrates (glucose, lactate, alanine, and butyrate) were omitted. After $30 \mathrm{~min}$, samples were removed for analysis. The remaining tubules were pelleted and then resuspended in fresh $95 \%$ air/ $5 \% \mathrm{CO}_{2}$-gassed, $\mathrm{pH} 7.4$ solution B with experimental agents as needed. Sodium butyrate in solution $B$ was replaced with $2 \mathrm{~mm}$ heptanoic acid during reoxygenation and supplemented with $250 \mu \mathrm{M}$ AMP, 0.5 $\mathrm{mg} / \mathrm{dl}$ delipidated albumin, and $4 \mathrm{~mm}$ each of $\alpha$ ketoglutarate and malate. After $60 \mathrm{~min}$ of reoxygenation, tubules were sampled for studies. Movies with perfused isolated tubules recorded in the presence and absence of fatty acids as Q:6 indicated were taken from C57BL/6 mice, which were killed under deep isoflurane anesthesia by decapitation. Kidneys were removed immediately, sliced, and transferred into incubation buffer $(140 \mathrm{mmol} / \mathrm{l}$ $\mathrm{NaCl}, 0.4 \mathrm{mmol} / \mathrm{l} \mathrm{K \textrm {K } _ { 2 }} \mathrm{PO}_{4}, 1.6 \mathrm{mmol} / \mathrm{l} \mathrm{K} \mathrm{HPO}_{4}, 1 \mathrm{mmol} / \mathrm{l}$ $\mathrm{MgSO}_{4}, 10 \mathrm{mmol} / \mathrm{l} \mathrm{Na}$-acetate, $1 \mathrm{mmol} / \mathrm{l} \alpha$-ketoglutarate, $1.3 \mathrm{mmol} / \mathrm{l} \mathrm{Ca-gluconate}$, and $5 \mathrm{mmol} / \mathrm{l}$ glycine, containing $48 \mathrm{mg} / \mathrm{l}$ trypsin inhibitor and $25 \mathrm{mg} / \mathrm{l}$ DNase I at $\mathrm{pH}$ 7.4). Proximal tubules (PTs) were isolated mechanically and transferred into the bath on a heated microscope stage (Axiovert 10 (PT1) or Axiovert 35 M). Tubules were held by a concentric glass pipette system. The rates of tubular perfusion via the micropipette were $10-20 \mathrm{nl} / \mathrm{min}$. The bath was thermostated at $37^{\circ} \mathrm{C}$, and continuous bath perfusion at $3-5 \mathrm{ml} / \mathrm{min}$ was obtained by gravity perfusion. PTs were monitored by a digital imaging system (Visitron Systems $\mathrm{GmbH}$ ) and analyzed by MetaFluor software. Brightfield images were obtained every 10-20 s and stored for off-line analysis. Solution I $(140 \mathrm{mmol} / \mathrm{l}$ $\mathrm{NaCl}, 0.4 \mathrm{mmol} / \mathrm{l} \mathrm{K \textrm {K } _ { 2 }} \mathrm{PO}_{4}, 1.6 \mathrm{mmol} / \mathrm{l} \mathrm{K} 2 \mathrm{HPO}_{4}, 1 \mathrm{mmol} / \mathrm{l}$ $\mathrm{MgCl}_{2}, 5 \mathrm{mmol} / \mathrm{l}$ glucose, $1.3 \mathrm{mmol} / \mathrm{l} \mathrm{Ca-gluconate}$, at $\mathrm{pH}$ 7.4) was used for fatty-acid depletion, and Solution II (140

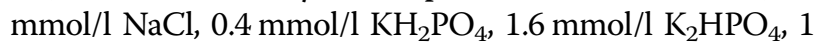
$\mathrm{mmol} / \mathrm{l} \mathrm{MgSO}_{4}, 1.3 \mathrm{mmol} / \mathrm{l} \mathrm{Ca-gluconate,} 10 \mathrm{mmol} / \mathrm{l} \mathrm{Na}$ acetate, $1 \mathrm{mmol} / \mathrm{l} \alpha$-ketoglutarate, $5 \mathrm{mmol} / \mathrm{l}$ glycine, and 5 $\mathrm{mmol} / \mathrm{l}$ glucose, at $\mathrm{pH}$ 7.4) was used for adapted PT substrate supply.

\section{Ex vivo analysis of synchronized renal tubular regulated necrosis}

Male MLKL-ko mice and respective male control mice were killed under deep isoflurane anesthesia by decapitation. Kidneys were removed immediately, sliced, and transferred into ice-cold dissection buffer (in mmol/l: 140 $\mathrm{NaCl}, 0.4 \mathrm{KH}_{2} \mathrm{PO}_{4}, 1.6 \mathrm{~K}_{2} \mathrm{HPO}_{4}, 1 \mathrm{MgSO}_{4}, 10 \mathrm{Na}$-acetate, $1 \alpha$-ketoglutarate, $1.3 \mathrm{Ca}$-gluconate, 5 glycine, 5 glucose, containing $48 \mathrm{mg} / \mathrm{l}$ trypsin inhibitor, $25 \mathrm{mg} / \mathrm{l}$ DNase I and $1.5 \mathrm{~g} / \mathrm{l}$ albumin at $\mathrm{pH} 7.4)$. S2 segments were isolated mechanically and transferred into the bath on a heated microscope stage (Axiovert $35 \mathrm{M}$ ). Tubules were held by a concentric glass pipette system ${ }^{1}$ and perfused with a rate of $10-20 \mathrm{nl} / \mathrm{min}$ with experimental solution (in $\mathrm{mmol} / \mathrm{l}$ : $140 \mathrm{NaCl}, 0.4 \mathrm{KH}_{2} \mathrm{PO}_{4}, 1.6 \mathrm{~K}_{2} \mathrm{HPO}_{4}, 1 \mathrm{MgSO}_{4}, 1.3 \mathrm{Ca}-$ gluconate, $10 \mathrm{Na}$-acetate, $1 \alpha$-ketoglutarate, 5 glycine, 5 glucose, at $\mathrm{pH} 7.4)$ containing $50 \mu \mathrm{mol} / \mathrm{l}$ erastin. The bath was thermostated at $37^{\circ} \mathrm{C}$ and continuous bath perfusion with experimental solution at $3-5 \mathrm{ml} / \mathrm{min}$ was obtained by gravity perfusion. PTs were monitored by a digital imaging system (Visitron Systems GmbH, Germany) and analyzed by MetaFluor software. Brightfield images were obtained every $20 \mathrm{~s}$ and stored for offline analysis and generation of time-lapse films.

\section{Mice}

All WT mice reported in this study were on C57BL/6 background. Eight to 12-week-old male C57BL/6 mice (average weight $\sim 23 \mathrm{~g}$ ) were used for all WT experiments, unless otherwise specified. MLKL-deficient mice were generously provided by James Murphy and Warren Alexander for the purpose of this investigation and have been described previously. All in vivo experiments were performed according to the Protection of Animals Act, after approval of the German local authorities or the 
Institutional Animal Care and Use Committee (IACUC) of the St. Jude Medical Department. In all experiments, mice were rigorously matched for age, sex, weight, and genetic background.

\section{TNFa-induced severe inflammatory response syndrome}

This model has also been referred to as TNF $\alpha$-induced shock by others and has been described in detail previously ${ }^{4}$. In our experiments, wild-type mice received intravenous (i.v.) injection of a single bolus of $25 \mu \mathrm{g}$ murine TNF $\alpha$ in $200 \mu \mathrm{l}$ PBS via the tail vein in the identical concentration in the presence or absence of phenytoin. Animals were under permanent observation and survival was checked every $30 \mathrm{~min}$.

\section{Murine ischemia-reperfusion injury}

Induction of kidney IRI was performed via a midline abdominal incision and a bilateral renal pedicle clamping for either $40 \mathrm{~min}$ (severe IRI, or "lethal-to-WT" IRI) or 27 min (mild IRI) using microaneurysm clamps (Aesculab). Throughout the surgical procedure, the body temperature was maintained between $36^{\circ} \mathrm{C}$ and $37^{\circ} \mathrm{C}$ by continuous monitoring using a temperature-controlled self-regulated heating system (Fine Science Tools). After removal of the clamps, reperfusion of the kidneys was confirmed visually. The abdomen was closed in two layers using standard 6-0 sutures. Sham-operated mice underwent the identical surgical procedures, except that microaneurysm clamps were not applied. To maintain fluid balance, all of the mice were supplemented with $1 \mathrm{ml}$ of prewarmed PBS administered intraperitoneally directly after surgery. All mice were killed $48 \mathrm{~h}$ after reperfusion for each experiment. All ischemia-reperfusion experiments were performed in a double-blinded manner. Where indicated, phenytoin was applied intraperitoneally $15 \mathrm{~min}$ before the onset of ischemia in a final volume of $200 \mu \mathrm{l}$. In those experiments, control mice received $200 \mu \mathrm{l}$ of PBS.

\section{Histology, immunohistochemistry, and evaluation of structural organ damage}

Organs were dissected as indicated in each experiment and infused with $4 \%$ neutral-buffered formaldehyde, fixated for $48 \mathrm{~h}$, dehydrated in a graded ethanol series and xylene, and finally embedded in paraffin. Paraffin sections $(3-5 \mu \mathrm{m})$ were stained with periodic acid-Schiff (PAS) reagent, according to the standard routine protocol. Stained sections were analyzed using an Axio Imager microscope (Zeiss) at $\times 200$ or $\times 400$ magnification. Micrographs were digitalized using an AxioCam MRm Rev. 3 FireWire camera and AxioVision ver. 4.5 software (Zeiss). Organ damage was quantified by two experienced pathologists in a double-blind manner on a scale ranging from 0 (unaffected tissue) to 10 (severe organ damage). For the scoring system, tissues were stained with PAS, and the degree of morphological involvement in renal failure was determined using light microscopy. The following parameters were chosen as indicative of morphological damage to the kidney after IRI: brush border loss, red blood cell extravasation, tubule dilatation, tubule degeneration, tubule necrosis, and tubular cast formation. These parameters were evaluated on a scale of $0-10$, which ranged from not present (0), mild (1-4), moderate ( 5 or 6$)$, severe ( 7 or 8 ), to very severe ( 9 or 10 ). Each parameter was determined on at least four different animals.

\section{Intravital microscopy}

In order to investigate renal hemodynamics, multiphoton microscopy experiments were performed. Mice were anesthetized by i.p. injections of ketamine/xylazine $(100 / 10 \mathrm{mg} / \mathrm{kg}$ of body weight) before surgery was performed on an operating table with a servo-controlled heating plate. The right carotid artery was cannulated using hand-drawn polyethylene tubing so that the arterial blood pressure and the heart rate could be measured continuously. A cannula was inserted into the right jugular vein for the injection of fluorescent dyes and for an intravenous fluid supplementation over the experiment $(12 \mu \mathrm{l} / \mathrm{g}$ body weight $/ \mathrm{h}$ of $0.9 \%$ saline). Finally, the left kidney was exposed by making a small flank incision.

Images were then acquired using an inverted Zeiss LSM 710 NLO confocal fluorescence microscope (Carl Zeiss) equipped with a servo-controlled warming plate to maintain the body temperature of the animal at $37^{\circ} \mathrm{C}$. Excitation was achieved using a Chameleon Ultra-II MP laser (Coherent) at $860 \mathrm{~nm}$.

Vasculature was labeled by injecting $80 \mu \mathrm{l}$ of Texas Red conjugated to $70 \mathrm{kDa}$ dextran (Invitrogen, $20 \mathrm{mg} / \mathrm{ml}$ stock solution purified by PD-10 Sephadex G-25M columns (GE Healthcare)) and cell nuclei were visualized using Hoechst 33342 (Invitrogen, $25 \mu \mathrm{l}$ of a $10 \mathrm{mg} / \mathrm{ml}$ solution).

\section{Measurement of peritubular capillary flow}

Peritubular capillary flow was investigated as described before $^{22,23}$. Briefly, z-stacks of ten randomly chosen regions within the renal cortex were acquired per animal. Per region, the diameter and red blood cell velocity of several capillaries were measured. The capillary diameter (d) was determined by measuring at the widest position of the investigated vessel throughout the z-stack. By injecting $70 \mathrm{kDa}$ dextran-Texas Red the plasma was labeled red, whereas the red blood cells appear as dark unstained objects inside the capillaries. The red blood cell velocity $(V)$ was thereby visualized and measured by performing a time $(t)$ series of 500 fast longitudinal line scans, applying a pixel dwell time of $1.97 \mu$ s. The total distance $(X)$ was 20 $\mu \mathrm{m}$ within the central axis of the capillary, displaying the movement of the RBC as dark bands within the Xt-scan. 
The velocity $(\mu \mathrm{m} / \mathrm{ms})$ of the $\mathrm{RBC}$ is inversely proportional to the slope of the evolved bands, which was calculated as $\Delta X / \Delta t$. Peritubular capillary flow $(\mathrm{nl} / \mathrm{min})$ was then calculated using the following formula:

Flow $=V \times((d / 2) 2 \times \pi)$.

\section{Protein kinase assays}

Kinase activities were assayed in appropriate kinase buffer, with either protein or peptide as substrate in the presence of $15 \mu \mathrm{M}$ or $30 \mu \mathrm{M}$ (for RIPK1) $\left[\gamma^{-}{ }^{34} \mathrm{P}\right]$ ATP $(3000 \mathrm{Ci} / \mathrm{mmol} ; 10 \mathrm{mCi} / \mathrm{ml})$ in a final volume of $30 \mu \mathrm{l}$ following the assay described in Bach et al. ${ }^{35}$. Controls were performed with appropriate dilutions of dimethylsulfoxide. Full-length kinases are used unless specified. Peptide substrates were obtained from Proteogenix (Oberhausbergen, France).

\section{Buffers}

(A) $10 \mathrm{~mm} \mathrm{MgCl}_{2}, 1 \mathrm{~mm}$ EGTA, $1 \mathrm{~mm}$ DTT, $25 \mathrm{~mm}$ Tris-

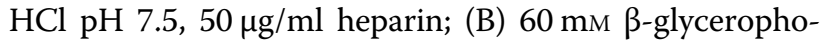
sphate, $30 \mathrm{~mm}$ p-nitrophenyl-phosphate, $25 \mathrm{~mm}$ MOPS (pH 7), 5 mм EGTA, $15 \mathrm{~mm} \mathrm{MgCl}_{2}, 1 \mathrm{~mm}$ DTT, $0.1 \mathrm{~mm}$ sodium orthovanadate; (R) $1.67 \mathrm{~mm}$ MOPS $\mathrm{pH} 7.2,0.83$ mм $\beta$-glycerophosphate, $1.33 \mathrm{~mm} \mathrm{MgCl} 2,0.83 \mathrm{~mm} \mathrm{MnCl}_{2}$, $0.33 \mathrm{~mm}$ EGTA, $0.13 \mathrm{~mm}$ EDTA, $16.67 \mu \mathrm{g} / \mathrm{ml}$ BSA, 0.017 mM DTT.

HsRIPK1 autophosphorylation assay was performed following the protocol described previously ${ }^{36}$ by Degterev et al. Kinase reactions were assayed in buffer $\mathrm{R}$ with $30 \mu \mathrm{M}$ of ATP for $30 \mathrm{~min}$ at $30^{\circ} \mathrm{C}$. Reactions were stopped by boiling in sample loading buffer for $3 \mathrm{~min}$ at $95^{\circ} \mathrm{C} .25 \mu \mathrm{l}$ of each reaction was loaded per well in pre-cast NuPage $12 \%$ Bis-Tris gel (Life Technology) and analyzed by SDSPAGE. The proteins were vizualized using Coomassie Blue staining. Typhoon PhosphorImager (GE Healthcare Life Sciences) was used to detect autophosphorylated RIPK1 band. Percent of inhibition were determined after quantification of the band intensities using Bio-Profil software (๑ Vilber-Lourmat).

HsRIPK3 (human, recombinant, expressed by baculovirus in Sf9 insect cells) was assayed in buffer R, with 0.1 $\mu \mathrm{g} / \mu \mathrm{l}$ of MBP as substrate.

HsPIM1 (human proto-oncogene, recombinant, expressed in bacteria) was assayed in buffer B, with $0.8 \mu \mathrm{g} /$ $\mu \mathrm{l}$ of histone H1 (Sigma \#H5505) as substrate.

$H s \mathrm{CDK} 2 /$ CyclinA (cyclin-dependent kinase-2, human, kindly provided by Dr. A. Echalier-Glazer, Leicester, UK) was assayed in buffer A $(+0.15 \mathrm{mg} / \mathrm{ml}$ of BSA $+0.23 \mathrm{mg} /$ $\mathrm{ml}$ of DTT), with $0.8 \mu \mathrm{g} / \mu \mathrm{l}$ of histone $\mathrm{H} 1$ as substrate.

$H s \mathrm{CDK}$ /CyclinT (human, recombinant, expressed by baculovirus in Sf9 insect cells) was assayed in buffer A $(+0.15 \mathrm{mg} / \mathrm{ml}$ of BSA $+0.23 \mathrm{mg} / \mathrm{ml}$ of DTT $)$, with 0.27 $\mu \mathrm{g} / \mu \mathrm{l}$ of the following peptide: YSPTSPSYSPTSPSYSPTSPSKKKK, as substrate.
$H s \mathrm{CDK} 5 / \mathrm{p} 25$ (human, recombinant, expressed in bacteria) was assayed in buffer $\mathrm{B}$, with $0.8 \mu \mathrm{g} / \mu \mathrm{l}$ of histone $\mathrm{H} 1$ as substrate.

SscGSK-3 $\alpha / \beta$ (glycogen synthase kinase-3, porcine brain, native, affinity purified) was assayed in buffer A $(+0.15 \mathrm{mg} / \mathrm{ml}$ of BSA $+0.23 \mathrm{mg} / \mathrm{ml}$ of DTT), with 0.010 $\mu \mathrm{g} / \mu \mathrm{l}$ of GS-1 peptide, a GSK-3-selective substrate (YRRAAVPPSPSLSRHSSPHQSpEDEEE, "Sp" stands for phosphorylated serine).

RnDYRK1A-kd (Rattus norvegicus, amino acids 1-499 including the kinase domain, recombinant, expressed in bacteria, DNA vector kindly provided by Dr. W. Becker, Aachen, Germany) was assayed in buffer A $(+0.5 \mathrm{mg} / \mathrm{ml}$ of BSA $+0.23 \mathrm{mg} / \mathrm{ml}$ of DTT) with $0.033 \mu \mathrm{g} / \mu \mathrm{l}$ of the following peptide: KKISGRLSPIMTEQ as substrate.

MmCLK1 (from Mus musculus, recombinant, expressed in bacteria) was assayed in buffer A $(+0.15 \mathrm{mg} / \mathrm{ml}$ of BSA $+0.23 \mathrm{mg} / \mathrm{ml}$ of DTT) with $0.027 \mu \mathrm{g} / \mu \mathrm{l}$ of the following peptide: GRSRSRSRSRSR as substrate.

\section{Measurement of $\left[\mathrm{Ca}^{++}\right] \mathrm{i}$ and patch clamp of TSZ- stimulated cells}

Measurement of the intracellular $\mathrm{Ca} 2+$ concentration were performed as described recently ${ }^{7}$. In brief, cells were loaded either with $5 \mu \mathrm{M}$ Fura2-AM (to measure global cytosolic Ca2 + changes) in Ringer solution at $37^{\circ} \mathrm{C}$ for 30 min. Fluorescence was detected at $37^{\circ} \mathrm{C}$, using an inverted microscope IMT-2 (Olympus, Nurnberg, Germany) and a high speed polychromator system (Visi- Chrome, Puchheim, Germany). The results were obtained at 340/380 $\mathrm{nm}$ fluorescence ratio (after background subtraction). After calibration ${ }^{7}$ intracellular $\mathrm{Ca} 2+$ concentrations were $^{2}$ calculated.

\section{Patch clamping}

Cells were grown on coated glass cover slips. If not indicated otherwise, patch pipettes were filled with a cytosolic-like solution containing $\mathrm{KCl} 30, \mathrm{~K}$-gluconate 95 , $\mathrm{NaH}_{2} \mathrm{PO}_{4}$ 1.2, $\mathrm{Na}_{2} \mathrm{HPO}_{4}$ 4.8, EGTA 1, Ca-gluconate $0.758, \mathrm{MgCl}_{2}$ 1.03, D-glucose 5, ATP 3, pH 7.2. The intracellular (pipette) $\mathrm{Ca} 2+$ activity was $0.1 \mu \mathrm{M}$. Coverslips were mounted in a perfused bath chamber on the stage of an inverted microscope (IM35, Zeiss) and kept at $37^{\circ} \mathrm{C}$. The bath was perfused continuously with Ringer solution at a rate of $8 \mathrm{ml} / \mathrm{min}$. Patch pipettes had an input resistance of 2-4M $\mathrm{M}$ when filled with the cytosolic-like (physiological) solution. Currents were corrected for serial resistance. The access conductance was measured continuously and was $60-140 \mathrm{nS}$. Currents (voltage clamp) and voltages (current clamp) were recorded using a patch clamp amplifier (EPC 7, List Medical Electronics, Darmstadt, Germany), the LIH1600 interface and PULSE software (HEKA, Lambrecht, Germany) as well as Chart software (AD Instruments, Spechbach, Germany). Data 
were stored continuously on a computer hard disc and analyzed using PULSE software. In regular intervals, membrane voltage $(\mathrm{Vc})$ was clamped in steps of $20 \mathrm{mV}$ from -100 to $+100 \mathrm{mV}$ from a holding voltage of -100 $\mathrm{mV}$. Current density was calculated by dividing whole cell currents by cell capacitance.

\section{Human kidney biopsy samples}

The human biopsies were obtained as indication biopsies for AKI at the University Hospital Cologne, Germany, strictly adhered to the statutes of the Declaration of Helsinki and the Declaration of Istanbul. Informed consent was obtained from all subjects prior to the start of the procedure.

\section{Statistics}

For all experiments, differences of datasets were considered statistically significant when $p$ values were lower than 0.05 , if not otherwise specified. Statistical comparisons were performed using the two-tailed Student's $t$ test. Asterisks are used in the figures to specify statistical significance $\left(" p<0.05 ;{ }^{* * *} p<0.02\right.$; $\left.{ }^{* * * *} p<0.001\right) . p$ values in survival experiments (Kaplan-Meier plots) were calculated using GraphPad Prism, ver. 5.04 software. Statistics are indicated as SD unless otherwise specified.

\section{Acknowledgements}

The Linkermann laboratory is supported by a Heisenberg Professorship grant provided by the German Research Foundation (DFG). This work was additionally supported by the German Research Foundation (DFG), Cluster of Excellence (EXC 306, project W TP1) to A.L. This work forms part of the MD thesis of W.T. and A.Z. W.T. is an EXC306-associated MD student. This project was additionally supported by the German Research Foundation (DFG) grants KU756/12-1 and SFB699A7/A12 to K.K. J.M.W. was supported by 101 BX002367, Department of Veterans Affairs. A.O. and A.B.S. were supported by ISCIII RETIC REDINREN RD16/0009/0001 FEDER funds, PI16/01900, Pl16/02057, and Miguel Servet program. The authors like to thank Jan Hinrich Bräsen for his help with the PAS staining and PMLKL immunofluorescence in the mouse experiments. We are grateful for the expert technical help by Maike Berger, Janina Kahl, Kaja Bruch, and Manuela Brandt for genotyping, as well as help with FACS and cell culture assays.

\section{Author details}

'Division of Nephrology, Medical Clinic 3, University Hospital Carl Gustav Carus, Technical University Dresden, Dresden, Germany. ${ }^{2}$ Department of Physiology, University of Kiel, Kiel, Germany. ${ }^{3}$ Sackler School of Graduate Biomedical Sciences, Tufts University School of Medicine, Boston, MA, USA. ${ }^{4}$ Department of Immunology, St. Jude Medical Research Hospital, Memphis, TN, USA. ${ }^{5}$ Institute for Physiology, University of Regensburg, Regensburg, Germany. ${ }^{6}$ Immunology Institute, Icahn School of Medicine at Mount Sinai, New York, NY 10029, USA. 'Department of Internal Medicine, University of Michigan, Ann Arbor, MI, United States. ${ }^{8}$ Nephrology, IIS-Fundacion Jimenez Diaz UAM, FRIAT and REDINREN, Madrid, Spain. ${ }^{9}$ Institute of Pathology, University of Cologne, Cologne, Germany. ${ }^{10}$ Protein Phosphorylation and Human Disease Laboratory, Station Biologique de Roscoff UPMC Univ Paris 06 CNRS USR3151, CS 90074 Sorbonne Universités 29688 Roscoff Cedex France. ${ }^{11}$ Blood Cell Development and Function Program, Fox Chase Cancer Center, Philadelphia, PA, USA. ${ }^{12}$ Medizinische Klinik und Poliklinik IV, Klinikum der LMU München, Munich, Germany

\section{Conflict of interest}

The authors declare that they have no conflict of interest.

\section{Publisher's note}

Springer Nature remains neutral with regard to jurisdictional claims in published maps and institutional affiliations.

Supplementary Information accompanies this paper at (https://doi.org/ 10.1038/s41419-018-0394-3).

Received: 7 February 2018 Accepted: 8 February 2018

Published online: 02 March 2018

\section{References}

1. Tonnus, W. \& Linkermann, A. The in vivo evidence for regulated necrosis. Immunol. Rev. 277, 128-149 (2017).

2. Land, W. G., Agostinis, P., Gasser, S., Garg, A. D. \& Linkermann, A. DAMPinduced allograft and tumor rejection: the circle is closing. Am. J. Transplant. https://doi.org/10.1111/ajt.14012 (2016).

3. Li, Y., Qian, L. \& Yuan, J. Small molecule probes for cellular death machines. Curr. Opin. Chem. Biol. 39, 74-82 (2017).

4. Linkermann, A. \& Green, D. R. Necroptosis. N. Engl. J. Med 370, 455-465 (2014)

5. Conrad, M., Angeli, J. P., Vandenabeele, P. \& Stockwell, B. R. Regulated necrosis: disease relevance and therapeutic opportunities. Nat. Rev. Drug Discov. 15, 348-366 (2016).

6. Vande Walle, L. \& Lamkanfi, M. Pyroptosis. Curr. Biol. 26, R568-R572 (2016).

7. Broz, P. \& Dixit, V. M. Inflammasomes: mechanism of assembly, regulation and signalling. Nat. Rev. Immunol. 16, 407-420 (2016).

8. Cho, Y. S. et al. Phosphorylation-driven assembly of the RIP1-RIP3 complex regulates programmed necrosis and virus-induced inflammation. Cell 137, 1112-1123 (2009).

9. He, S. et al. Receptor interacting protein kinase-3 determines cellular necrotic response to TNF-alpha. Cell 137, 1100-1111 (2009).

10. Zhang, D. W. et al. RIP3, an energy metabolism regulator that switches TNFinduced cell death from apoptosis to necrosis. Science 325, 332-336 (2009).

11. Sun, L. et al. Mixed lineage kinase domain-like protein mediates necrosis signaling downstream of RIP3 kinase. Cell 148, 213-227 (2012).

12. Zhao, J. et al. Mixed lineage kinase domain-like is a key receptor interacting protein 3 downstream component of TNF-induced necrosis. Proc. Natl. Acad. Sci. USA 109, 5322-5327 (2012).

13. Daniels, B. P. et al RIPK3 restricts viral pathogenesis via cell death-independent neuroinflammation. Cell 169, 301-313.e311 (2017).

14. Wegner, K. W., Saleh, D. \& Degterev, A. Complex pathologic roles of RIPK1 and RIPK3: moving beyond necroptosis. Trends Pharmacol. Sci. 38, 202-225 (2017).

15. Linkermann, $A$. et al Two independent pathways of regulated necrosis mediate ischemia-reperfusion injury. Proc. Natl. Acad. Sci. USA 110, 12024-12029 (2013).

16. Newton, $K$. et al. RIPK3 deficiency or catalytically inactive RIPK1 provides greater benefit than MLKL deficiency in mouse models of inflammation and tissue injury. Cell Death Differ. 23, 1565-1576 (2016).

17. Dillon, C. P. et al. RIPK1 blocks early postnatal lethality mediated by caspase-8 and RIPK3. Cell 157, 1189-1202 (2014).

18. Kaiser, W. J. et al. RIP1 suppresses innate immune necrotic as well as apoptotic cell death during mammalian parturition. Proc. Natl. Acad. Sci. USA 111, 7753-7758 (2014).

19. Rickard, J. A. et al. RIPK1 regulates RIPK3-MLKL-driven systemic inflammation and emergency hematopoiesis. Cell 157, 1175-1188 (2014).

20. Greve, A. S. et al P2X1, P2X4, and P2X7 receptor knock out mice expose differential outcome of sepsis induced by alpha-haemolysin producing Escherichia coli. Front. Cell Infect. Microbiol. 7, 113 (2017).

21. Linkermann, A. et al. Two independent pathways of regulated necrosis mediate ischemia-reperfusion injury. Proc. Natl. Acad. Sci. USA 110, 12024-12029 (2013).

22. Gong, Y.-N. et al ESCRT-III acts downstream of MLKL to regulate necroptotic cell death and its consequences. Cell 169, 286-300.e216 (2017).

23. Linkermann, A. Nonapoptotic cell death in acute kidney injury and transplantation. Kidney Int. 89, 46-57 (2016).

24. Dixon, S. J. et al. Ferroptosis: an iron-dependent form of nonapoptotic cell death. Cell 149, 1060-1072 (2012).

25. Yagoda, $\mathrm{N}$. et al. RAS-RAF-MEK-dependent oxidative cell death involving voltage-dependent anion channels. Nature 447, 864-868 (2007). 
26. Linkermann, A. et al The RIP1-kinase inhibitor necrostatin-1 prevents osmotic nephrosis and contrast-induced AKI in mice. J. Am. Soc. Nephrol. 24 1545-1557 (2013).

27. Harris, P. A. et al Discovery of a first-in-class receptor interacting protein 1 (RIP1) kinase specific clinical candidate (GSK2982772) for the treatment of inflammatory diseases. J. Med. Chem. 60, 1247-1261 (2017).

28. Harris, P. A. et al DNA-encoded library screening identifies benzo[b][1,4]oxazepin-4-ones as highly potent and monoselective receptor interacting potein 1 kinase inhibitors. J. Med. Chem. 59, 2163-2178 (2016).

29. Najjar, M. et al Structure guided design of potent and selective ponatinibbased hybrid inhibitors for RIPK1. Cell 10, 1850-1860 (2015).

30. Teng, $X$. et al Structure-activity relationship study of novel necroptosis inhibitors. Bioorg. Med. Chem. Lett. 15, 5039-5044 (2005).
31. Takeuchi, R. et al Phenytoin-induced gingival overgrowth caused by death receptor pathway malfunction. Oral. Dis. 23, 653-659 (2017).

32. Sarhan, M., Land, W. G.., Tonnus, W., Hugo, C. P. \&, Linkermann, A. Origin and Consequences of Necroinflammation. Physiol Rev. 98, 727-780 (2018).

33. Harris, P. A. et al Discovery of small molecule RIP1 kinase inhibitors for the treatment of pathologies associated with necroptosis. ACS Med. Chem. Lett. 4, 1238-1243 (2013)

34. Mandal, P. et al RIP3 induces apoptosis independent of pronecrotic kinase activity. Mol. Cell 56, 481-495 (2014).

35. Bach, S. et al. Roscovitine targets, protein kinases and pyridoxal kinase. J. Biol. Chem. 280, 31208-31219 (2005).

36. Degterev, A. et al. Identification of RIP1 kinase as a specific cellular target of necrostatins. Nat. Chem. Biol. 4, 313-321 (2008). 